\title{
PEMBIAYAAN MUSYARAKAH DI BAIT AL-MAL WA AT-TAMWIL (BMT) AN-NUR REWWIN WARU SIDOARJO
}

\author{
Nur Afrida \\ Jl. Granit Kumala 17 no. 11 Perum KBD, Driyorejo, Gresik \\ noermafpoex@gmail.com
}

Nur Lailatul Musyafa'ah

UIN Sunan Ampel Surabaya

nurlailatul@uinsby.ac.id

\begin{abstract}
This article discusses musyarakah financing at BMT An-Nur Rewwin Waru Sidoarjo in the perspective of Islamic law. This research is field research and qualitative. Data were collected through observation, interview, and documentation techniques. The data analyzed using a descriptive analysis method with an inductive mindset describes the general description of musyarakah financing at BMT An-Nur Rewwin first, then analyzed with the concept of musyarakah in the DSN-MUI fatwa number 08/DSN-MUI/ IV/2000 concerning Musyarakah Financing. This study concludes that the musyarakah financing at BMT An-Nur is done using the customer registering at the administration and filling out the registration form with the designation of a business. It can be disbursed after being approved by the director. In reality, the customer uses the loan not for business as in the application, but the funds are used for consumptive needs. In the perspective of Islamic law, the Musyarakah financing at BMT An-Nur Rewwin in terms of the legal contract is valid because it meets the requirements and pillars contained in the Fatwa of DSN-MUI number 08/DSN-MUI/IV/2000 concerning Musyarakah Financing. However, it was canceled because it was wrong. one party misuses the allotted loan funds. In line with the conclusions above, it is recommended that BMT An-Nur Rewwin tighten supervision on the use of funds by customers to avoid misuse. For customers, they should be more trustworthy in the use of loan funds for business.
\end{abstract}

Keywords: Financing, Musyarakah, Bait al-Mal wa al-Tamwil.

Abstrak: Artikel ini membahas tentang pembiayaan musyarakah di BMT An-Nur Rewwin Waru Sidoarjo dalam perspektif hukum Islam. Penelitian ini adalah penelitian lapangan dan kualitatif. Data dihimpun melalui teknik observasi, wawancara dan dokumentasi. Setelah data tersebut terkumpul, kemudian dianalisis dengan menggunakan metode deskriptif analisis dengan pola pikir induktif, yaitu mendeskripsikan gambaran umum mengenai pembiayaan musyarakah di BMT AnNur Rewwin terlebih dahulu, kemudian dianalisis dengan konsep musyarakah dalam fatwa DSN-MUI nomor 08/DSN-MUI/IV/2000 tentang Pembiayaan Musyarakah. Kesimpulan dari penelitian ini adalah dalam pembiayaan musyarakah di BMT An-

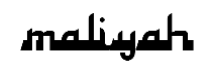

Jurnal Hukum Bisnis Islam

Volume 8, Nomor 2, Desember 2018

p-ISSN: 2088-4869/ e-ISSN: 2597-4351 
Nur dilakukan dengan cara nasabah mendaftar di bagian administrasi dan mengisi formulir pendaftaran dengan peruntukan suatu usaha, kemudian dapat dicairkan setelah disetujui oleh direktur. Dalam kenyataannya nasabah menggunakan pinjaman tersebut bukan untuk usaha sebagaimana dalam pengajuan tetapi dana terseut digunakan untuk kebutuhan konsumtif. Dalam perspektif hukum Islam, pembiayaan musyarakah di BMT An-Nur Rewwin dari segi akad hukumnya sah, karena memenuhi syarat dan rukun yang terdapat dalam Fatwa DSN-MUI nomor 08/DSN-MUI/IV/2000 tentang Pembiayaan Musyarakah, namun menjadi batal karena salah satu pihak menyalahgunakan peruntukan dana pinjaman tersebut. Sejalan dengan kesimpulan di atas, maka disarankan bagi pihak BMT An-Nur Rewwin hendaknya memperketat pengawasan penggunaan dana oleh nasabah untuk menghindari penyalahgunaan. Bagi nasabah, hendaknya lebih amanah dalam penggunaan pinjaman dana untuk usaha.

Kata Kunci: Pembiayaan, musyarakah, Bait al-Mal wa al-Tamwil.

\section{Pendahuluan}

Di Indonesia, terjadi peningkatan yang cukup pesat terhadap adanya Lembaga keuangan syariah. Keberadaan Lembaga keuangan syariah menjadi solusi bagi umat Islam di bidang ekonomi. Bait al-Mal wa al-Tamwil (BMT) merupakan salah satu bentuk lembaga keuangan syariah. BMT berperan penting dalam pemberdayaan ekonomi masyarakt, khususnya ekonomi mikro, kecil dan menengah. Keberadaan BMT diharapkan mampu membantu masyarakat dalam memenuhi kebutuhan ekonomi, khususnya bagi masyarakat yang memulai usaha namun tidak memiliki modal biaya yang cukup.

Perkembangan BMT adalah hal yang ditunggu bagi umat Islam yang menghendaki berinteraksi secara syariah dan menghindari praktik riba. Saat ini di Indonesia banyak bermunculan BMT yaitu lembaga keuangan syariah yang paling sederhana. BMT bergerak di kalangan masyarakat ekonomi menengah ke bawah, yang berupaya meningkatkan usaha produktif dan investasi untuk mengembangkan usaha ekonomi pengusaha kecil dengan berdasarkan prinsip ekonomi syariah dengan melalui pembiayaan. ${ }^{1}$

Pembiayaan yang sering dilakukan di BMT adalah melalui kerjasama, yaitu BMT membiayai anggota atau nasabah BMT

\footnotetext{
${ }^{1}$ Makhalul Ilmi, Teori Dan Praktik Mikro Keuangan Syariah (Yogyakarta: UII Press, 2002), 49.
} 
dengan memberikan sejumlah modal, baik berupa uang tunai atau barang sebagai upaya meningkatkan produktivitas usaha. Dengan melalui transaksi kerjasama tersebut, BMT dan nasabah ersepakat dalam nisbah bagi hasil. ${ }^{2}$

Sistem bagi hasil diterapkan di produk pembiayaan berbasis syariah bila kerjasama tersebut mendapatkan keuntungan, dan jika mendapatkan kerugian maka lembaga keuangan syariah dan nasabah saling menanggung kerugian sebagai resiko adanya kerjasama. Hal tersebut adalah bentuk pembiayaan musyarakah yaitu pembiayaan yang didasarkan atas percampuran dua harta dalam suatu usaha. ${ }^{3}$

Musyarakah secara bahasa berasal dari kata syirkah yang berarti percampuran (al-ikhtilath). ${ }^{4}$ Musyarakah merupakan akad dari dua pihak atau lebih antara pengusaha dengan pemilik dana/modal sebagai mitra yang membiayai investasi usaha pengusaha dengan sistem bagi hasil.

Dalam hal ini, pemilik modal memiliki hak intervensi dalam mengelola usaha namun bukan suatu keharusan. Para pihak yang bekerjasama dapat membagi pekerjaan dalam mengelola usaha berdasarkan kesepakatan dan bagi yang mencurahkan tenaga dan keahlian untuk usaha tersebut dapat meminta gaji atau upah atas usahanya. ${ }^{5}$ Dalam hal ini BMT dan pengusaha bisa ikut serta mengelola usaha dengan membagi tugas sesuai kesepakatan dengan pembagian keuntungan sesuai kesepakatan.

Pembiayaan musyarakah didasarkan pada al-Qur'an surat Shad ayat 24:

"Dan sesungguhnya memang banyak di antara orangorang yang bersekutu itu berbuat dzalim kepada yang

${ }^{2}$ Muhammad Ridwan, Manajemen Baitul Mal Wa Tamwil (BMT) (Yogyakarta: UII Press, 2004), 169.

${ }^{3}$ Hendi Suhendi, Fiqh Muamalah (Jakarta: Raja Grafindo Persada, 2006), 125.

${ }^{4}$ Mahmud Yunus, Kamus Arab-Indonesia (Jakarta: PT Mahmud Yunus Wa

Dzurriyah, 1972), 196.

${ }^{5}$ Ascarya, Akad Dan Produk Bank Syariah (Jakarta: Rajawali Press, 2013), 51. 
lain, kecuali orang-orang beriman dan mengerjakan kebajikan... (Q.S. Sad :24)"6

Kerjasama dalam Islam diperbolehkan, karena tidak ada dalil yang melarangnya. ${ }^{7}$ Kerjasama penting dilakukan antara sesama manusia sebagai makhluk sosial. Banyak manfaat yang didapatkan dari kerjasama dalam bidang ekonomi, karena bisa mendatangkan kemaslahatan, kebahagiaan dan kesejahteraan, sebagaimana dijelaskan dalam firman Allah SWT:

"Dan tolong-menolonglah kamu dalam (mengerjakan) kebajikan dan taqwa dan jangan tolong-menolong dalam berbuat dosa dan pelanggaran. (Q.S. Al-Maidah:2)"8

Di antara BMT yang berada di Sidoarjo adalah BMT AnNur Rewwin. BMT tersebut menawarkan beberapa pembiayaan, di antaranya pembiayaan musyarakah. Pembiayaan musyarakah diajukan nasabah ke BMT untuk modal usaha. Namun, dalam praktiknya meskipun di akad tertuang untuk modal usaha terdapat beberapa nasabah yang menggunakan uang tersebut untuk kebutuhan konsumtif bukan sebagai modal usaha. Hal tersebut dapat mencederai akad musyarakah, karena sifat kejujuran merupakan hal yang sangat penting dalam akad musyarakah.

Berdasarkan hal tersebut, penulis tertarik membahas pembiayaan musyarakah di BMT An-Nur Rewwin Waru Sidoarjo, untuk dianalisis dengan konsep musyarakah dalam hukum Islam.

Penelitian ini adalah penelitian lapangan dan kualitatif. Pengumpulan data dilakukan dengan observasi, wawancara dan dokumentasi. Data yang terkumpul kemudian dianalisis secara deskriptif dengan pola induktif, yaitu mendeskripsikan gambaran umum mengenai pembiayaan musyarakah di BMT An-Nur Rewwin Kecamatan Waru Kabupaten Sidoarjo terlebih

${ }^{6}$ Departemen Agama Republik Indonesia, Al-Qur'an Dan Terjemahnya (Bekasi: Al-Qur'an dan Terjemahnya, 2012), 650.

${ }^{7}$ Adiwarman Karim, Bank Islam: Analisis Fiqih Dan Keuangan (Jakarta: PT

Raja Grafindo Persada, 2004), 33.

${ }^{8}$ Departemen Agama Republik Indonesia, Al-Qur'an Dan Terjemahnya, 15657. 
dahulu, kemudian dianalisis dengan konsep musyarakah dalam hukum Islam dan fatwa DSN-MUI nomor 08/DSNMUI/IV/2000 tentang Pembiayaan Musyarakah.

\section{Profil BMT An-Nur Rewwin Waru Sidoarjo}

BMT An-Nur berada di masjid An-Nur yang terletak di Perumahan Rewwin Waru Sidoarjo Jawa Timur. Masjid An-Nur pada awalnya adalah sebuah musholla yang dibangun pada tahun 1991 berukuran 6x6 M2 dengan teras berukuran 1,5x1,5M2. 2 tahun kemudian (1993), musholla An-Nur diresmikan menjadi masjid An-Nur. ${ }^{9}$

Masjid An-Nur memiliki yayasan bernama "Yayasan AnNur Rewwin" dengan akte pendirian nomor 68, tanggal 18 Juli 1995 pada notaris Trining Ariswati, SH. Yayasan tersebut berpijak pada al-Qur'an dan hadis dalam melaksanakan ibadah dan memiliki motto "Mensejahterakan Sosial dan Mencerahkan Ummat untuk Menjadi Muslim yang Haqiqi".

Pada tahun 2004, yayasan An-Nur Rewwin mengganti organ yayasan dan mengesahkannya dalam Akta nomor 23, tanggal 16 April 2008 di Notaris: Wachid Hasyim, SH, serta Menteri Hukum dan HAM nomor: AH4.2445.AH.01.02 tanggal: 12 Juni 2008. Pada perombakan kepengurusan Yayasan (menyesuaikan dengan Undang-undang yang baru/20132018), telah melibatkan personil baru yang direkrut dari jamaah Masjid An-Nur Rewwin untuk turut serta menjadi pengurus yayasan, dengan harapan "Semoga akan muncul dan selalu muncul angkatan-angkatan baru yang lebih muda, lebih Islami dan lebih peduli".10

Yayasan An-Nur Rewwin membentuk bidang-bidang guna menunjang kegiatan masjid. Bidang-bidang tersebut adalah:

1. Bidang Ketakmiran (Pengelola Kegiatan Masjid)

Bidang ini bertanggungjawab terhadap kegiatan di masjid di antaranya:

a. Kajian ahad petang (kajian setelah shalat Maghrib)

\footnotetext{
${ }^{9}$ Yudi Budiman, "Wawancara," January 9, 2017.

${ }^{10}$ Ibid.
} 
b. Belajar Bahasa Arab untuk mempermudah membaca alQur'an yang diadakan hari Ahad setelah shalat Isya'

c. Belajar membaca al-Qur'an yang diadakan hari Jum'at setelah shalat Isya'.

d. Kultum yang disampaikan jama'ah masjid setiap Ahad setelah shalat shubuh.

e. Menerima/menyalurkan zakat fitri serta qurban bekerjasama dengan Rukun Tetangga sekitar sebagai koordinator panitia pelaksana kegiatan.

2. Bidang Pendidikan

Bidang ini bertanggungjawab terhadap pengelolaan TPQ dan madrasah diniyah (MADIN). Izin pendirian Madin dari Departemen Agama RI kabupaten Sidoarjo nomor: Kd.13.15/5/PP.008/2033/2007, tanggal: 20 Juni 2007 dengan statistik nomor: 412351514234. Saat ini santriwan/santriwati sejumlah 70 orang yang dibimbing oleh 5 ustadzah.

3. Bidang Kewanitaan

Bidang kewanitaan ini bertanggung jawab dalam mengkoordinir kegiatan ibu-ibu jamaah masjid An-Nur Rewwin yang meliputi Baksos (Bakti Sosial), Kajian Jum'at Petang yang diadakan setelah shalat Maghrib, belajar terjemah al-Qur'an dan memahami kandungan al-Qur'an yang diadakan setiap hari Jum'at setelah shalat isya', dan kegiatan belajar menyulam setiap hari Rabu setelah shalat isya'.

4. Bidang Pembangunan

Bidang ini bertanggungjawab dalam pembangunan, yang saat ini dalam proses pembangunan gedung MADIN/TPQ serta fasilitasnya dengan RAB Rp. 2.600.000.

5. Bidang Usaha Dana

Bidang ini bertanggungjawab dalam pengelolaan infak yang didapat dari donatur rutin tiap RT dan pembuatan iklan di buku khutbah milik masjid An-Nur untuk menunjang kegiatan yayasan serta ikut mengelola usaha Baitul Mal wat Tamwil (BMT) An-Nur Rewwin.

6. Bidang Kepemudaan 
Bidang kepemudaan ini bertugas mengkoordinir kegiatan IRMA (Ikatan Remaja Masjid). Kegiatan IRMA ini hanya diikuti perempuan guna mempersiapkan generasi muda Islami yang berimtaq tinggi. Kegiatan-kegiatan IRMA diantaranya adalah Baksos (bakti sosial) yang diadakan setiap bulan Ramadhan, donor darah setiap 3 bulan sekali, dan parade An-Nur (pentas seni) tiap 3 bulan sekali.

Berdirinya BMT An-Nur berawal dari perbincangan para jama'ah masjid. Ketika itu, saat menunggu azan Maghrib membicarakan cara menambah dana donator masjid An-Nur. Selama ini Yayasan An-Nur Rewwin dibidang usaha dana hanya mengandalkan dana donatur dan membuat iklan pada buku khotbah di Masjid An-Nur untuk melakukan perawatan masjid serta penambahan kapasitas maupun fasilitas yang ada di masjid.

Dalam perbincangan tersebut muncul usulan membuka usaha di yayasan masjid agar bisa menghasilkan keuntungan yang dapat dimanfaatkan untuk memenuhi kebutuhan masjid. Usulan tersebut ditanggapi secara serius dan akhirnya diperoleh keputusan mendirikan usaha koperasi syariah di bawah yayasan masjid An-Nur Rewwin.

Pada hari selasa tanggal 10 April 2007, bertempat di Masjid An-Nur Rewwin, Waru Sidoarjo diadakan rapat rencana pendirian koperasi yang dihadiri oleh 21 orang dari 40 orang pendiri koperasi, dilaksanakan mulai pukul 20:00 wib dan berakhir pukul 22:00 WIB. Rapat tersebut berhasil menentukan pengurus koperasi syariah sebagai berikut:

1. Ketua

Ditunjuk sebagai ketua adalah Gunung Rijadi. Tugas ketua adalah bertanggung jawab atas semua tindakan yang dilakukan oleh Koperasi serba Usaha An-Nur Rewwin Sidoarjo, baik mengenai putusan dalam pemberian pembiayaan maupun putusan dalam tindakan ketika ada permasalahan di Koperasi serba Usaha An-Nur Rewwin Sidoarjo.

2. Wakil ketua 
Ir. H Yudi Budiman terpilih sebagai Wakil Ketua mendampingi Gunung Rijadi. Wakil ketua bertugas mendata karakter calon nasabah, mendata obyek yang dijaminkan seperti, cek fisik kendaraan atau rumah yang disertifikatnya akan dijaminkan. Menganalisa periodik pembiayaan yang akan dikeluarkan, serta membantu penagihan kepada nasabah yang terlambat melakukan pembayaran.

3. Sekretaris

Ditunjuk sebagai sekretaris koperasi adalah Djumharjadi. Sekretaris bertugas mendata nasabah yang mengajukan pembiayaan dan bertugas menjadi marketing koperasi. Marketing Koperasi Serba Usaha An-Nur Rewwin Sidoarjo dilakukan melalui penyebaran brosur, mensponsori kegiatan masjid, adanya pemberitahuan saat rapat untuk mengenalkan Koperasi Serba Usaha An-Nur Rewwin Sidoarjo serta dengan acara perbincangan dari teman ke teman.

4. Bendahara

Yang menjadi bendahara koperasi adalah Drs. H. Bambang Waluyojati. Bendahara bertugas merealisasikan pembiayaan dan menerima pembayaran dari nasabah, baik berupa pembayaran pembiayaan atau menabung.

Koperasi Serba Usaha An-Nur Rewwin, semakin hari semakin berkembang maka pada tahun 2011 menambah pengurus baru yaitu menjadikan Nur Kholis sebagai admin koperasi. Tugas admin adalah membantu bendahara dalam merealisasikan pembiayaan dan menerima pembayaran dari nasabah serta pembukuan keuangan di Koperasi serba Usaha An-Nur Rewwin.

Setelah melakukan studi banding ke beberapa daerah di antaranya ke Malang, Probolinggo dan Tulungagung, berdasarkan kesepakatan bersama, maka Koperasi Serba Usaha An-Nur Rewwin diganti menjadi BMT A-Nur Rewwin. Perubahan tersebut dilakukan karena nama BMT lebih sesuai sebagai nama usaha yang dikelola masjid An-Nur Rewwin.

Penghimpunan dana awal dilakukan dengan menjual harga saham dengan harga Rp. 600.000,00 perlembar. 
Penjualan saham tersebut dalam satu bulan berhasil mengumpulkan modal awal sebesar Rp. 100.000.000,00.11 Modal tersebut berkembang dengan baik, namun gedung masih menyewa dan bukan milik sendiri.

Setelah satu tahun, pada saat RUPS (Rapat Umum Pemegang Saham), untuk mengembangkan usaha BMT An-Nur Rewwin Sidoarjo maka perlu pengumpulan dana baru. Berdasarkan hal tersebut hasil RUPS menyatakan membuka kembali penjualan saham dengan harga yang lebih kecil dari penjualan saham yang pertama sebesar Rp. 300.000.00. Diharapkan dengan harga tersebut, banyak warga yang menginvestasikan dananya di BMT An-Nur Rewwin. Akhirnya terkumpul dana sebesar Rp. 100.000.000 dan dana tersebut dapat menjadikan BMT An-Nur Rewwin sidoarjo semakin maju dan berkembang.

Pendirian Koperasi Serba Usaha An-Nur Rewwin dilakukan untuk membantu pengembangan masjid An-Nur Rewwin dan memantu memenuhi kebutuhan jama'ahnya. Adapun visi misnya adalah sebagai berikut:

1. Meningkatkan kesejahteraan dan taraf hidup anggota dan masyarakat sekitar.

2. Menjadi gerakan ekonomi rakyat.

3. Sumber dana bagi sosio spiritual masyarakat di Masjid AnNur Rewwin.

Identitas BMT An-Nur, yaitu sebagai berikut:

Tanggal berdiri $\quad: 20$ Mei 2007

Nomer HAM

: AH4.2445.AH.01.02

Badan Hukum

$$
\text { : 03/BH/403.62/IV/2007 }
$$

Alamat lengkap

Rewwin

No telp

Fax

: Jl. Raya Cendrawasih no. 27

Perkembangan anggota, yaitu sebagai berikut:

\begin{tabular}{|l|l|l|l|}
\hline NO & Tahun & Anggota & Kenaikan(\%) \\
\hline 1 & 2007 & 146 & 0 \\
\hline
\end{tabular}

${ }^{11}$ Gunung Rijadi, “Wawancara,” January 9, 2017. 
Pembiayaan Musyarakah di BMT An-Nur Rewwin ...

\begin{tabular}{|l|l|l|l|}
\hline 2 & 2008 & 268 & 83.6 \\
\hline 3 & 2009 & 294 & 84.3 \\
\hline 4 & 2010 & 501 & 1.4 \\
\hline 5 & 2011 & 590 & 17.8 \\
\hline 6 & 2012 & 647 & 9.7 \\
\hline 7 & 2013 & 830 & 28.3 \\
\hline 8 & 2014 & 990 & 19.3 \\
\hline 9 & 2015 & 1060 & 7.1 \\
\hline
\end{tabular}

Perkembangan karyawan, yaitu sebagai berikut:

\begin{tabular}{|c|c|c|c|c|c|}
\hline \multirow[t]{2}{*}{ NO } & \multirow[t]{2}{*}{ TAHUN } & \multicolumn{2}{|c|}{$\begin{array}{l}\text { JENIS } \\
\text { KELAMIN }\end{array}$} & \multirow[t]{2}{*}{ JUMLAH } & \multirow[t]{2}{*}{$\begin{array}{l}\text { KENAIKAN } \\
(\%)\end{array}$} \\
\hline & & $\mathrm{Lk}$ & $\operatorname{Pr}$ & & \\
\hline 1 & 2007 & 4 & 0 & 4 & 0 \\
\hline 2 & 2008 & 4 & 0 & 4 & 0 \\
\hline 3 & 2009 & 4 & 0 & 4 & 0 \\
\hline 4 & 2010 & 5 & 0 & 5 & 25 \\
\hline 5 & 2011 & 5 & 0 & 5 & 0 \\
\hline 6 & 2012 & 5 & 0 & 5 & 0 \\
\hline 7 & 2013 & 5 & 0 & 5 & 0 \\
\hline 8 & 2014 & 5 & 1 & 6 & 25 \\
\hline 9 & 2015 & 5 & 1 & 6 & 0 \\
\hline 10 & 2016 & 5 & 1 & 6 & 0 \\
\hline
\end{tabular}

Jumlah Karyawan per-Juni 2016 BMT An-Nur Rewwin Waru Jawa Timur adalah 6 orang.

Izin pendirian serta pelaksanaan kegiatan atau operasional berdasarkan Akte Perubahan Notaris Wachid Hasyim, SH, nomor 39 tahun 2007, Jalan Raya Rajawali Utara no. 1 Rewwin, Waru Sidoarjo. ${ }^{12}$

Susunan kepengurusan BMT An-Nur Rewwin Waru Jawa Timur periode 2015-2016 adalah sebagai berikut:
1. Ketua
: Gunung Rijadi

2. Wakil Ketua

: H Yudi Budiman

3. Sekretaris

: Djumhariadi

4. Bendahara

: H Bambang Waluyo

5. Administrasi

: Nur Kholis

12 Budiman, "Wawancara."

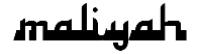

Jurnal Hukum Bisnis Islam

Volume 8, Nomor 2, Desember 2018 p-ISSN: 2088-4869/ e-ISSN: 2597-4351 
Nur Afrida, Nur Lailatul Musyafa'ah

6. Administrasi : Sad Retno Harini

7. Officer : Denny

Dewan Pengurus Syariah (DPS) BMT An-Nur Rewwin:

1. Drs. Akhmad Mukarram, M.Hum

2. Drs. Djoko Poerwantoro

3. Drs. Achmadi Joedhono

4. Drs. H. Djoko Poerwantoro, M.Pd.

\section{Produk-produk BMT An-Nur Rewwin Waru Sidoarjo}

Pada awal berdirinya BMT, BMT An-Nur Rewwin hanya memiliki dua produk yaitu produk simpanan dan produk jasa. Seiring berjalannya waktu, produk di BMT An-Nur semakin berkembang menjadi memiliki beberapa produk. Produkproduk yang ada di BMT An-Nur Rewwin Sidoarjo dibagi menjadi dua, yaotu produk simpanan An-Nur dan produk pembiayaan An-Nur. Setiap produk memiliki macam-macam bentuk sebagaimana berikut:

1. Produk-produk Simpanan An-Nur

Produk simpanan An-Nur memiliki tiga bentuk simpanan, yaitu simpanan mudharabah, simpanan qurban dan aqiqah dan simpanan pendidikan.

a. Simpanan Mudharabah:

Simpanan mudharabah adalah simpanan yang penyetoran dan pengambilannya dapat dilakukan sewaktu-waktu selama kas buka serta akan diberikan bagi hasil yang menarik. Setoran simpanan pertama minimal Rp. $50.000,00$ dan setoran berikutnya minimal Rp. 10.000,00. Simpanan mudharabah ini bisa digunakan sebagai jaminan pembiayaan.

b. Simpanan Qurban dan Aqiqah:

Simpanan qurban dan aqiqah adalah simpanan yang bertujuan untuk pembelian hewan qurban atau aqiqah dan hanya dapat diambil menjelang Hari Raya Qurban atau mejelang hajat aqiqah. Besarnya setoran adalah tetap (menyesuaikan dengan harga hewan) dengan setoran simpanan pertama minimal Rp. 100.000,00 dan 
setoran berikutnya perminggu Rp. 25.000,00 atau perbulan Rp 100.000,00.

c. Simpanan Pendidikan

Simpanan pendidikan adalah simpanan yang bertujuan untuk biaya pendidikan anak mulai TK hingga Perguruan Tinggi, yang dapat digunakan untuk pembiayaan uang gedung, SPP dan pembelian peralatan sekolah lainnya. Simpanan ini bisa juga sebagai simpanan harian atau mingguan atau juga bulanan dari siswa, baik dikoordinir pihak sekolah maupun berhubungan langsung.

2. Produk-produk Pembiayaan An-Nur

Terdapat empat produk pembiayaan di BMT An-Nur Rewwin, yaitu pembiayaan musyarakah, murabahah, al-qarh al-hasan, dan gadai syariah.

a. Pembiayaan Musyarakah:

Pembiayaan musyarakah adalah pembiayaan dalam bentuk modal atau dana yang diberikan oleh BMT (Bait al-Mal Wa at-Tamwil) An-Nur Rewwin, untuk dikelola oleh nasabah dalam suatu usaha yang halal dan telah disepakati bersama. Dalam pembiayaan ini nasabah dan BMT (Bait al-Mal Wa at-Tamwil) An-Nur Rewwin sepakat untuk berbagi hasil atas pendapatan usaha tersebut.

b. Pembiayaan Murabahah atau Bai' Bi Tsaman Ajil:

Pembiayaan murabahah adalah pembiayaan dengan sistem jual beli dalam bentuk penyediaan objek atau barang halal apa saja berdasarkan pesanan nasabah, serta BMT (Bait al-Mal Wa at-Tamwil) An-Nur Rewwin menjualnya kepada nasabah. Pembayaran dapat dilakukan sekaligus sesuai jatuh tempo yang disepakati (murabahah) atau diangsur sesuai jangka waktu yang disepakati (Bai' Bi Tsaman Ajil)

c. Pembiayaan al-Qard Al-Hasan:

Pembiayaan lunak yang diberikan atas dasar kewajiban sosial semata, dimana penerima pembiayaan hanya dituntut mengembalikan pokok pembiayaan ditambah infak untuk masjid An-Nur Rewwin.

d. Gadai Syariah (Ar Rahn) 
Pembiayan ar-rahn adalah pembiayaan dengan perjanjian menyerahkan barang atau harta nasabah sebagai jaminan. Dalam pembiayaan ini nasabah akan dibebani untuk memberikan biaya penyimpanan atau penitipan barang berharga.

\section{Praktik Pembiayaan Musyarakah di BMT An-Nur Rewwin Waru Sidoarjo}

BMT An-Nur Rewwin memiliki tiga bentuk produk pembiayaan, yaitu musyarakah, mudharabah, qard hasan. Di antara ketiga produk tersbeut, bentuk pembiayaan di BMT AnNur Rewwin yang paling diminati oleh nasabah adalah pembiayan musyarakah karena untuk modal suatu usaha.

Pembiayaan musyarakah di BMT AN-Nur Rewwin Waru Sidoarjo adalah pembiayaan berbentuk modal yang diberikan oleh BMT An-Nur Rewwin kepada nasabah untuk dijadikan modal usaha yang halal dan yang telah disepakati kedua belah pihak. Dalam pembiayaan tersebut, BMT An-Nur Rewwin dan nasabah bersepakat dalam bagi hasil atas pendapatan usaha mereka.

Berkaitan dengan pembiayaan musyarakah di BMT AnNur Rewwin, BMT akan melihat karakter dan loyalitas nasabah sebagai bahan pertimbangan dalam menyetujui pembiayaan nasabah. Dalam hal ini, BMT melihat karakter dan loyalitas nasabah melalui sikap kejujuran dan kesungguhan nasabah dalam melengkapi persyaratan pembiayaan di BMT An-Nur Rewwin.

Prosedur yang harus dilalui nasabah ketika mengajukan akad pembiayaan musyarakah di BMT An-Nur Rewwin adalah sebagai berikut ${ }^{13}$ :

1. Nasabah membawa fotocopy KTP, fotocopy Kartu keluarga, dan fotocopy surat-surat yang akan dijadikan sebagai jaminan pembiayaan musyarakah.

2. Nasabah melakukan pendaftaran di bagian administrasi dan mengisi formulir pendaftaran (warna kuning).

13 Ibid. 
3. Berkas-berkas dari nasabah diberikan map warna biru dan diberi nomor.

4. Berkas tersebut diserahkan kepada pak Yudi selaku AO untuk selanjutnya diperiksa tentang kelengkapan dan kesesuian surat-surat dengan barang yang dijadikan jaminan.

5. Setelah selesai pemeriksaan, maka berkas tersebut diberikan kepada Pak Gunung untuk selanjutnya nasabah dipanggil untuk wawancara dengan pak Gunung mengenai pembiayaan yang akan diberikan beserta bagi hasilnya.

Mayoritas nasabah BMT An-Nur Rewwin lebih memilih pembiayaan musyarakah daripada pembiayaan yang lain, karena dapat digunakan sebagai modal usaha dengan pembagian hasil 60\%:40\% dari keuntungan. Hal tersebut sebagaimana dijelaskan oleh Gunung Rijadi, direktur BMT AnNur Rewwin:

"Pada awalnya produk yang digunakan di BMT An-Nur Rewwin yakni musyarakah, murabahah, qard hasan. Namun yang lebih dominan digunakan adalah akad musyarakah. Musyarakah dipilih karena diperuntukkan untuk sektor pedagang sayur, pedagang keliling, toko klontong, usaha jasa kos-kosan, warung kopi, terus pengrajin sandal dan sepatu. Inti dipilihnya akad musyarakah di BMT An-Nur Rewwin itu karena memang dibuat untuk suatu modal usaha. Dan persentase bagi hasil yang diambil oleh BMT An-Nur Rewwin 60\%, untuk nasabah sendiri $40 \%$ dari keuntungan". ${ }^{14}$

Pendapat tersebut dikuatkan oleh Yudi Budiman selaku wakil direkur BMT An-Nur Rewwin:

"Di BMT An-Nur Rewwin ada tiga pembiayaan yakni musyarakah, murabahah, dan qard. Tapi yang lebih banyak digunakan di BMT An-Nur Rewwin adalah pembiayaan musyarakah. Karena pembiayaan musyarakah digunakan untuk usaha bisnis, seperti:

${ }^{14}$ Rijadi, "Wawancara.” 
pedagang sayur keliling, pedagang kaki lima, usaha depot.

Pembagian bagi hasil 60\% dan 40\%." 15

Pembiayaan musyarakah dapat membantu nasabah yang ingin berwirausaha sendiri namun tidak mempunyai modal atau modal yang mereka punya kurang maka pembiayaan musyarakah adalah sebuah pilihan yang tepat untuk memulai berwirausaha. Meskipun demikian, pembiayaan musyarakah di BMT An-Nur Rewwin tersebut tak lepas dari kendala, diantaranya pembayaran kurang lancar, atau usaha nasabah mengalami penurunan. Untuk mengatasi hal tersebut maka BMT akan memberikan teguran atau pendekatan face to face. Hal tersebut sebaimana disampaikan Guntur:

"Permasalahan dalam pembiayaan musyarakah seperti halnya ada yang nunggak dalam pembiayaan, pembiayaan kurang lancar atau macet. Alasan nasabah yang nunggak atau tidak bisa membayar cicilan karena dipecat dalam pekerjaannya. Solusi untuk menghindari pembiayaan musharakah yang bermasalah yakni dengan melakukan pendekatan secara face to face, dilihat dulu persoalan penyebabnya nanti BMT An-Nur Rewwin yang memberikan solusi untuk mengatasinya".16

Sependapat dengan hal tersebut, Yudi Budiman selaku wakil direkur BMT An-Nur Rewwin menambahkan:

"Permasalahan dalam pembiayaan musyarakah seperti usaha yang dijalani mengalami penurunan. Solusi yang dipakai BMT An-Nur Rewwin berupa teguran kepada nasabah dan melakukan pendekatan secara empat mata atau face to face". 17

Pembiayaan musyarakah di BMT An-Nur Rewwin dilakukan untuk diperuntukkan sebagai modal usaha nasabah. Namun dalam praktiknya, setelah mengajukan pembiayaan musyarakah terdapat beberapa nasabah yang menggunakan uang modal dari BMT tersebut dipakai untuk memenuhi

\footnotetext{
15 Budiman, "Wawancara."

16 Rijadi, "Wawancara."

${ }^{17}$ Budiman, "Wawancara."
} 
kebutuhan konsumtif bukan untuk modal usaha. Dalam hal ini, penulis menemukan tiga nasabah yang melakukan hal tersebut: 1. Wati (bukan nama sebenarnya) dari Rewwin Waru Sidoarjo. Wati mengajukan pembiayaan musyarakah dengan mejadikan BPKB motornya sebagai jaminan untuk memenuhi syarat pembiayaan. Wati menjelaskan bahwa ia mengajukan pembiayaan untuk modal usaha online namun dalam praktiknya ia menggunakan uang tersebut untuk pembuatan jemuran dan kamar:

"Saya sering mbak pinjam di BMT An-Nur Rewwin. Awal pinjaman dalam form akad untuk usaha online tapi dalam penggunaan pinjaman digunakan untuk perbaikan rumah mbak. Untuk pembuatan jemuran sama pembuatan satu kamar saja buat anak cowok. Alhamdulillah, karena saya sudah kenal baik dengan pihak BMT An-Nur Rewwin, jadinya saya dipinjami mbak". 18

2. Siti dari Waru Sidoarjo.

Siti mengajukan pembiayaan musyarakah untuk usaha toko klontong, namun dalam praktiknya Siti menggunakan uang modal tersebut untuk membayar hutang.

"Dulu pernah mbak pinjam di BMT An-Nur Rewwin, pinjamnya dulu di form akad untuk buka toko klontong tapi dalam penggunaannya untuk bayar hutang, karena saya bingung mau pinjam kemana, akhirnya saya datang untuk mengajukan pinjaman di BMT An-Nur Rewwin, untuk melunasi hutang saya tersebut". ${ }^{19}$

Untuk mendapat pembiayaan tersebut, Siti menjadikan BPKB motornya sebagai jaminan.

3. Yuni, dari Kepuh Kiriman Waru Sidoarjo.

Yuni mengajukan pembiayaan musyarakah di BMT An-Nur untuk modal usaha toko ATK, namun dalam kenyataannya ia menggunakan uang modal tersebut untuk membayar SPP

${ }^{18}$ Retno, "Nasabah," Wawancara, January 10, 2017.

${ }^{19}$ Siti Aminah, "Nasabah," Wawancara, January 10, 2017. 
anaknya. Sebagai salah satu syarat pembiayaan musyarakah, maka Yuni menjaminkan BPKB motornya.

"Kapan hari saya pernah mbak mengajukan pembiayaan musyarakah di BMT An-Nur Rewwin, pinjaman di form akad untuk buka toko ATK tapi dalam penggunaan pinjaman untuk membayar SPP sekolah anak saya. Alhamdulilah saya dipinjami oleh pihak BMT An-Nur Rewwin mbak, karena saya kenal dekat sama pihak BMT An-Nur Rewwin".20

Berdasarkan data di atas diketahui bahwa, terdapat nasabah yang mengajukan pembiayaan musyarakah tidak menggunakan dananya untuk modal sebagaimana yang diajukan, tetapi menggunakan dana tersebut untuk kepentingan yang lain. Wati mengajukan pembiayaan musyarakah usaha online tapi digunakan untuk membangun jemuran dan kamar, Siti mengajukan pembiayaan musyarakah untuk modal toko tapi dana tersebut digunakan untuk membayar hutang, begitu juga dengan Yuni yang mengajukan pembiayaan musyarakah untuk toko ATK tapi dana yang didapat digunakan untuk membayar SPP.

Dari segi pengajuan pembiayaan musyarakah, nasabah telah mengisi formulir yang disediakan dan menyebutkan keperluan usaha yang akan dijalankan. BMT An-Nur memberikan persetujuan karena sudah ada rasa percaya kepada nasabah. Dalam hal ini Gunung selaku direktur BMT An-Nur Rewwin menjelaskan:

"Dalam pengawasan pembiayaan musyarakah di BMT AnNur Rewwin untuk sebuah usaha bersama dilakukan setiap satu bulan sekali, apabila pihak nasabah membayar cicilan beserta bagi hasil yang telah disepakati, kemudian dari pihak nasabah setelah memperoleh keuntungan dalam usaha yang dijalankan bersama tersebut, nasabah setiap satu bulan sekali pergi ke BMT An-Nur Rewwin untuk membayar cicilan, setelah itu barulah pihak BMT An-Nur Rewwin menanyakan bagaimana perkembangan usaha tersebut, tetapi dalam pengawasannya dari pihak

${ }^{20}$ Yunita, "Nasabah," Wawancara, January 10, 2017. 
BMT An-Nur Rewwin hanya menanyakan saja perkembangan usaha tersebut, tanpa turun langsung ke lapangan yaitu tanpa melihat langsung keadaan usaha yang dijalankan bersama, hanya memberikan modal saja kepada nasabah". 21

Berdasarkan keterangan di atas diketahui bahwa BMT An-Nur Rewwin memiliki kepercayaan yang tinggi terhadap nasabah, bahwa nasabah akan menggunakan dana tersebut sesuai dengan usaha yang tercantum di dalam formulir pengajuan, tanpa mengecek ke lapangan.

Berkaitan dengan kasus penyalahgunaan penggunaan dana tersebut, Achmadi, dewan pengawas syariah (DPS) BMT An-Nur Rewwin menyatakan bahwa nasabah tersebut harus dibina dan tetap berkewajiban melunasi dana pinjamannya:

"Dalam solusi nasabah yang menyalahi ketentuan yang telah disepakati di awal akad, seperti menggunakan dana dalam akad musyarakah yang seharusnya digunakan untuk suatu usaha dengan sistem bagi hasil, tetapi digunakan sebagai dana kebutuhan konsumtif atau pribadi, maka pihak BMT An-Nur Rewwin tetap menjalankan pembiayaan tersebut tetapi pihak BMT AnNur Rewwin mengadakan pembinaan dan sosialisasi terhadap nasabah serta menganggap sebagai kerugian bagi BMT, namun nasabah tetap harus mengembalikan sejumlah dana yang dipinjam". ${ }^{22}$

\section{Analisis Praktik Pembiayaan Musyarakah di BMT An-Nur Rewwin Kecamatan Waru Kabupaten Sidoarjo}

Kerjasama di bidang ekonomi sangat dianjurkan di dalam agama Islam, sebagaimana di dalam Islam dianjurkan untuk saling tolong menolong dan saling berbagi keuntungan. Sebaliknya, Islam sangat melarang tindak penipuan karena hal tersebut bisa merugikan berbagai pihak. Kerjasama dalam

\footnotetext{
${ }^{21}$ Rijadi, "Wawancara."

22 Achmadi Joedhono, “Dewan Pengawas Syariah,” Wawancara, July 28, 2017.
} 
bidang ekonomi penting dilakukan untuk dapat memenuhi kebutuhan hidup.

Berkaitan dengan kerjasama dalam bidang ekonomi, maka di dalam agama Islam dikenal istilah musyarakah. Musyarakah adalah kerjasama antara dua orang atau lebih dalam bidang modal dan usaha dengan berbagi keuntungan sesuai kesepakatan. Hal tersebut diperbolehkan sebagaimana didasarkan pada surat An-Nisa ayat 12, yaitu:

"Dan bagianmu (suami-suami) adalah seperdua dari harta yang ditinggalkan oleh istri-istrimu, jika mereka tidak mempunyai anak. Jika mereka (istri-istrimu) itu mempunyai anak, maka kamu mendapat seperempat dari harta yang ditinggalkannya setelah (dipenuhi) wasiat yang mereka buat atau (dan setelah dibayar) utangnya. Para istri memperoleh seperempat harta yang kamu tinggalkan jika kamu tidak mempunyai anak. Jika kamu mempunyai anak, maka para istri memperoleh seperdelapan dari harta yang kamu tinggalkan (setelah dipenuhi) wasiat yang kamu buat atau (dan setelah dibayar) utang-utangmu. Jika seseorang meninggal, baik laki-laki maupun perempuan yang tidak meninggalkan ayah dan tidak meninggalkan anak, tetapi mempunyai seorang saudara laki-laki (seibu) atau seorang saudara perempuan (seibu), maka bagi masing-masing dari kedua jenis saudara itu seperenam harta. Tetapi jika saudarasaudara seibu itu lebih dari seorang, maka mereka bersama-sama dalam bagian yang sepertiga itu, setelah (dipenuhi wasiat) yang dibuatnya atau (dan setelah dibayar) utangnya dengan tidak menyusahkan (kepada ahli waris). Demikianlah ketentuan Allah. Allah Maha Mengetahui. Maha Penyantun". (Q.S. Nisa:12) ${ }^{23}$

Selain itu, dalam fatwa DSN-MUI nomor 08/DSNMUI/IV/2000 tentang pembiayaan musyarakah dijelaskan bahwa syirkah adalah izin untuk bertindak secara hukum bagi kedua belah pihak yang bekerjasama terhadap harta mereka,

${ }^{23}$ Departemen Agama Republik Indonesia, Al-Qur'an Dan Terjemahnya, 80. 
yakni salah satu pihak dari dua pihak yang melakukan perserikatan mengizinkan kepada pihak yang lain untuk melakukan perbuatan hukum atau tidak melakukan perbuatan hukum terhadap harta yang dimiliki dua orang atau lebih, serta hak untuk melakukan perbuatan hukum itu tetap melekat terhadap masing-masingnya.

Dalam rukun dari akad musyarakah adalah sebagai berikut:

1. Pelaku akad, yaitu para mitra usaha

2. Objek akad, yaitu yang mencakup modal atau pekerjaan

3. Shighah, yaitu ijab dan qabul. ${ }^{24}$

Praktik pembiayaan musyarakah di BMT An-Nur Rewwin telah memenuhi rukun di atas. Kerjasama dilakukan antara pelaku akad yaitu pihak MBT An-Nur Rewwin dengan nasabah, BMT sebagai pemilik modal dan nasabah sebagai pengelola usaha, dengan keuntungan dibagi bersama sesuai kesepakatan. Hal tersebut sesuai dengan konsep musyarakah di dalam agama Islam bahwa apabila usaha tersebut untung, maka keuntungan akan dibagi kepada para mitra sesuai dengan nisbah yang telah disepakati, sedangkan apabila usaha itu rugi maka akan ditanggung bersama sesuai dengan porsi modal yang disertakan setiap mitra. ${ }^{25}$

BMT An-Nur Rewwin, hanya menyetujui pembiayaan musyarakah yang diperuntukkan bagi usaha yang halal, sebagaimana yang tertulis di formulir pengajuan. Hal tersebut sesuai dengan ajaran Islam bahwa di antara syarat musyarakah adalah kerjasama dilakukan untuk usaha yang tidak bertentangan dengan syariat Islam.

Hal ini seperti yang dikemukakan oleh ulama Hasby AshShiddieqi bahwa musyarakah adalah akad yang berlaku antara dua orang atau lebih untuk ta'awun dalam bekerja pada suatu usaha dan membagi keuntungannya. ${ }^{26}$

\footnotetext{
${ }^{24}$ Naf'an, Pembiayaan Musharakah Dan Mudharabah, 98.

${ }^{25}$ Naf' an, Pembiayaan Musharakah Dan Mudharabah (Yogyakarta: Graha Ilmu, 2014), 95.

${ }^{26}$ Hasby Ash-Shiddieqi, Pengantar Fiqh Muamalah (Jakarta: Bulan Bintang, 1984), 89.
} 
Dalam penggunaan dana yang disalahgunakan nasabah karena tidak sesuai dengan akad yang tertera, yaitu tertulis dalam akad bahwa dana akan digunakan modal usaha tetapi dalam praktiknya digunakan untuk memenuhi kebutuhan lain yaitu membangun jemuran dan kamar, membayar hutang dan membayar SPP, menandakan adanya sikap tidak amanah dari nasabah. Hal ini menjadikan yang akad awalnya sah karena sudah memenuhi rukun dan syarat akad, tetapi menjadi batal karena ada salah satu pihak yang tidak amanah. Hal ini sesuai dengan Hadis Rasulullah Saw yaitu:

"Aku adalah orang ketiga dari dua hamba-Ku yang bekerja sama selama keduanya tidak berkhianat. Jika salah satunya berkhianat, maka aku akan keluar dari keduanya dan penggantinya adalah syetan". (HR. Abu Daud) ${ }^{27}$

Berdasarkan hadis tersebut diketahui bahwa kejujuran dan amanah sangat ditekankan dalam musyarakah. Jika ada yang berkhianat atau tidak jujur maka ia telah keluar dari konsep musyarakah.

Penyalahgunaan pembiayaan tersebut bisa tidak terjadi jika dilakukan dengan pembiayaan jenis yang lain misalnya pembiayaan murabahah untuk membeli jemuran dan bahan bangunan kamar, atau pembiayaan qard hasan untuk biaya SPP dan membayar hutang. Pembinaan yang dilakukan pihak BMT terhadap nasabah yang tidak jujur, sangat dianjurkan dalam Islam sebagai bentuk edukasi terhadap nasabah. Dalam hal ini pengawasan BMT terhadap usaha nasabah perlu ditingkatkan agar tidak terjadi lagi penyalahgunaan dana pembiayaan musyarakah.

\section{Penutup}

Berdasarkan pemaparan di atas dapat disimpulkan bahwa praktik pembiayaan musyarakah di BMT An-Nur Rewwin Kecamatan Waru Kabupaten Sidoarjo, dimulai dengan nasabah mendaftar di bagian administrasi dan mengisi formulir

\footnotetext{
27 Abu Dawud, "Mausu'ah Al-Hadith Ash-Sharif," in Sunan (Beirut: Maktab Ad-Dirasat Wal-Buhuts Fi Darrul Fikr, 1991), 238.
} 
pendaftaran dengan peruntukkan untuk suatu usaha, kemudian dapat dicairkan setelah disetujui oleh direktur.

Dalam praktiknya, terdapat beberapa nasabah yang menggunakan dana modal usaha tersebut tidak sesuai dengan usaha yang tertulis di forulir tetapai digunakan untuk kebutuhan konsumtif, yaitu Wati mengajukan pembiayaan musyarakah usaha online tapi digunakan untuk membangun jemuran dan kamar, Siti mengajukan pembiayaan musyarakah untuk modal toko tapi dana tersebut digunakan untuk membayar hutang, begitu juga dengan Yuni yang mengajukan pembiayaan musyarakah untuk toko ATK tapi dana yang didapat digunakan untuk membayar SPP.

Penyimpangan pembiayaan musyarakah di BMT An-Nur Rewwin Kecamatan Waru Kabupaten Sidoarjo dalam awal akadnya sah, karena memenuhi syarat dan rukun yang terdapat dalam Fatwa DSN-MUI nomor 08/DSN-MUI/IV/2000 tentang Pembiayaan Musyarakah yang Diperuntukkan untuk Usaha. Akan tetapi, batal ketika salah satu pihak menyalahgunakan peruntukkan dana pinjaman, di mana dana yang seharusnya untuk usaha digunakan untuk kebutuhan konsumtif.

Sejalan dengan kesimpulan di atas, maka kepada pihak BMT An-Nur Rewwin, hendaknya lebih selektif dan berhati-hati dalam memberikan pinjaman terhadap nasabah, serta turut andil dalam melakukan pengawasan dan melihat langsung usaha yang dijalankan bersama. Bagi nasabah, hendaknya lebih amanah dalam penggunaan pinjaman dana untuk usaha, dalam arti tidak menyalahgunakan pinjaman dana tersebut untuk kepentingannya sendiri atau konsumtif.

\section{Daftar Pustaka}

Ascarya. Akad dan Produk Bank Syariah. Jakarta: Rajawali Pers, 2011.

Dawud, Abu. "Sunan Abu Dawud". Hadith no. 2936. Kitab: AlBuyu'. Bab: ash-Shirkah dalam Mausu'ah al-Hadith ash-Sharif. Beirut: Maktab Ad-Dirasat Wal-Buhuts Fi Darrul Fikr, 1991. 
Nur Afrida, Nur Lailatul Musyafa'ah

Departemen Agama Republik Indonesia. Al-Qur'an dan Terjemahnya. Bekasi: Cipta Bagus Segara, 2012.

Departemen Pendidikan Dan Kebudayaan. Kamus Besar Bahasa Indonesia. Jakarta: Balai Pustaka, 1997.

Fatmah. Kontrak Bisnis Syariah. Surabaya: UIN Sunan Ampel Press, 2014.

Hasanudin, Maulana. Perkembangan Akad Musyarakah. Jakarta: Kencana, 2012.

Ilmi, Makhalul. Teori dan Praktek Mikro Keuangan Syariah. Yogyakarta: UII Press, 2002.

Jazil, Saiful. Fiqih Mu'amalah. Surabaya: UIN Sunan Ampel Press, 2014.

Karim, Adiwarman. Bank Islam Analisa Fiqh dan Keuangan. Yogyakarta: IIIT Indonesia, 2003.

Naf'an. Pembiayaan Musyarakah dan Mudharabah. Yogyakarta: Graha Ilmu, 2014.

Ridwan, Muhammad. Manajemen Baitul Maal Wa Tamwil (BMT). Yogyakarta: UII Press, 2004.

Shiddieqi (Ash), Hasby. Pengantar Fiqh Muamalah. Jakarta: Bulan Bintang, 1984.

Suhendi, Hendi. Fiqh Muamalah. Jakarta: PT Raja Grafindo Persada, 2006.

Yunus, Mahmud. Kamus Arab-Indonesia. Jakarta: PT Mahmud Yunus Wa Dzurriyah, 1972. 